\title{
Are Climates in Canada and the United States Suitable for the European Spruce Bark Beetle, Ips typographus, and Its Fungal Associate, Endoconidiophora polonica?
}

\author{
Kishan R. Sambaraju * and Chantal Côté
}

Citation: Sambaraju, K.R.; Côté, C. Are Climates in Canada and the United States Suitable for the European Spruce Bark Beetle, Ips typographus, and Its Fungal Associate, Endoconidiophora polonica? Forests 2021, 12, 1725. https://doi.org/ $10.3390 /$ f12121725

Academic Editor: Jose Negron

Received: 28 October 2021

Accepted: 3 December 2021

Published: 7 December 2021

Publisher's Note: MDPI stays neutral with regard to jurisdictional claims in published maps and institutional affiliations.

Copyright: (c) 2021 by the authors. Licensee MDPI, Basel, Switzerland. This article is an open access article distributed under the terms and conditions of the Creative Commons Attribution (CC BY) license (https:// creativecommons.org/licenses/by/ $4.0 /)$.
Natural Resources Canada, Canadian Forest Service, Laurentian Forestry Centre, 1055 du P.E.P.S., P.O. Box 10380, Stn. Sainte-Foy, Québec, QC G1V 4C7, Canada; chantal.cote@nrcan-rncan.gc.ca

* Correspondence: kishan.sambaraju@nrcan-rncan.gc.ca; Tel.: +1-418-648-7063

\begin{abstract}
Invasions of exotic forest insects and pathogens can devastate evolutionarily naïve habitats and could cause irreversible changes to urban and natural ecosystems. Given the ever-increasing volume of trade in wood and plant stock worldwide, establishment of non-native pests under climate change is one of the most important forest health concerns currently. The European spruce bark beetle, Ips typographus, is a damaging, phloem-feeding insect of Norway spruce, Picea abies, in Eurasia. Endoconidiophora polonica is the most virulent ophiostomatoid fungal associate of I. typographus. Spruce species native to North America are susceptible to this insect-pathogen complex. We studied the suitability of 'current' (1970-2000) and future climates (2021-2100) in Canada and the United States for these two species via ensemble species distribution models. We also determined overlapping regions favorable to both I. typographus and E. polonica. Our results indicate that, currently, climate is particularly suitable for I. typographus and E. polonica in western Canada and throughout the United States. Northward shifts in climatic suitability are projected to occur in Canada for both species under climate change. By the end of the 21st century, a coast-to-coast corridor of climatic suitability for I. typographus and E. polonica will occur in Canada under high-temperature regimes.
\end{abstract}

Keywords: Ips typographus; Endoconidiophora polonica; climatic suitability; modelling; mapping

\section{Introduction}

Invasions of non-native forest pests are a growing concern to governments, forest managers, and individuals worldwide as they can cause widespread, and in some cases, uncontrollable ecological and economic impacts. Tree mortality resulting from exotic pest invasions disrupts interconnected ecological phenomena such as nutrient cycles, carbon sequestration, biodiversity, tree composition and age-class structure, and forest succession [1,2]. Interceptions of exotic forest insect and pathogen species have dramatically increased over the past several decades in North America, raising serious biosecurity concerns. Structural and wood packaging materials (such as crates and pallets) associated with imports of various goods and commodities and import of live plants are often associated with exotic forest insects and pathogens [3-8]. Establishment and spread of even a small percentage of non-native pests can have serious economic impacts. For example, a recent assessment of the economic costs associated with exotic wood and phloem-feeding insects was estimated at >USD 2 billion per year for the United States alone [4]. Although a similar comprehensive economic analysis encompassing major exotic forest pathogens in North America has not been undertaken (but see [9]), in certain cases, their overall impacts are comparable or even exceed the effects attributed to established exotic insects [10-12].

Post-introduction abundances, spread patterns, drivers of differential spread rates, and damages caused by various exotic forest insects and pathogens in North America and around the world are increasingly being documented in the research literature [13-17]. For instance, the emerald ash borer (Agrilus planipennis Fairmaire) (EAB), a buprestid beetle 
native to Asia, is a transcontinental pest of ash trees (Fraxinus spp.) $[18,19]$. The EAB has spread at a rapid rate (57 km per year by one estimate, [13]) in the United States and Canada since it was first discovered in 2002 in Detroit (MI, USA) and Windsor (ON, Canada). This phloem-feeding insect has already killed tens of millions of ash trees in North America and continues to endanger the survival of the remaining ash trees. Forest diseases such as chestnut blight caused by the fungal pathogen Cryphonectria parasitica (Murrill) M.E. Barr and sudden oak death caused by Phytophthora ramorum Werres, De Cock \& Man in 't Veld offer insights to the deleterious impacts of exotic pathogens on native trees and ecosystems $[12,20]$. As climate change could favorably alter habitat suitability for exotic pests in the future [21], it is necessary to identify potentially risky alien species and examine the possibility of their establishment in novel habitats where critical forest resources may be at risk.

Bark beetles, woodborers, and wood wasps account for a significant proportion of all arthropods intercepted on wood packaging associated with imported materials in Canada and the United States [5-7]. Among these insects, the European spruce bark beetle, Ips typographus L. (Coleoptera: Curculionidae: Scolytinae), is one of the most important and frequently intercepted at the ports of entry $[3,5,6]$. Ips typographus is a phloem-feeding bark beetle and a key natural disturbance agent in forests of Eurasia, causing extensive mortality of Norway spruce, Picea abies L., in this region during outbreaks. In addition, I. typographus can survive and reproduce on North American spruce species [22,23]. A blue stain-causing virulent fungus, Endoconidiophora polonica (Siemaszko) Z. W. de Beer, T. A. Duong \& M. J. Wingf., comb. nov. [Basionym: Ophiostoma polonicum Siemaszko $\equiv$ Ceratocystis polonica (Siemaszko) C. Moreau] [24], is vectored by I. typographus in Eurasia [25,26], although their association is spatio-temporally inconsistent in its native range (see [25]). Endoconidiophora polonica is considered the most pathogenic among fungal associates of I. typographus $[27,28]$. Upon introduction into a live Norway spruce tree through beetle attack, E. polonica rapidly invades the sapwood. It disrupts the water transport weakening the tree, which allows the beetle to overcome the host defenses and colonize the tree. Ips typographus is highly attracted to E. polonica-colonized host substrate derived from Norway spruce, black spruce, or white spruce [29]. Artificial inoculations have shown that E. polonica can kill key North American spruce trees (Picea spp.) and Douglas fir, Pseudotsuga menziesii (Mirb.) Franco [30]. Other native and planted, non-native conifers in North America could be at varying risk from I. typographus and E. polonica [22,23,30-32] (Table S1). Given the frequent interceptions of I. typographus at ports of entry in North America, it is possible that this exotic insectpathogen complex could eventually establish when favorable conditions arise. However, the potential for establishment of these two species in North American spruce habitats has not been studied to date. To our knowledge, only one study [33] has thus far explored the climatic suitability of I. typographus in North America.

Species distribution models (SDMs) are a powerful set of modeling algorithms that associate species occurrences with predictors such as climatic variables in order to characterize habitat suitability for a target species or to predict potential distributional changes over space and/or over time [34-36]. These modeling approaches, in contrast to more process-based distribution models that require detailed information on dynamic biological processes of the study organism [37], use empirical distributions of target species, are flexible (e.g., use presence, presence-absence, presence-background species data), and are applicable at different spatial scales. A large body of knowledge has accumulated in the past decades over the usage of SDMs to model species distributions across different ecosystems [34]. With respect to exotic forest insects, pathogens, and habitat suitability models, however, more suitability assessments are needed, especially of exotic forest pathogens as few studies address this topic [38]. Therefore, the purpose of this study was to (a) develop predictive models and maps for I. typographus and E. polonica in Canada and the United States on the basis of the SDM framework, (b) characterize and highlight coinciding conducive habitats for both of these species in this region, and (c) describe the changes in 
favorable climatic zones for I. typographus and E. polonica over future time periods under two climate change scenarios (SSP2-4.5 and SSP5-8.5).

\section{Materials and Methods}

\subsection{Distribution Data}

Occurrence data for I. typographus and E. polonica were collected from several sources such as scientific publications, theses, books, and the Global Biodiversity Information Facility (GBIF) (http:/ /www.gbif.org [accessed on 2 December 2021]). For E. polonica, in addition to the above sources, fungal collection databases were also searched (e.g., Westerdijk Fungal Biodiversity Institute (CBS-KNAW collections), https:/ /wi.knaw.nl/ [accessed on 2 December 2021]). Site coordinates (latitude and longitude), if published, were directly recorded from the source. When geo-referenced data were lacking, for example when only location name was mentioned in the data source, we used Google Earth (https:/ / www.google.ca/earth/ [accessed on 2 December 2021]) or web-based resources to identify the target location and record the coordinates of the nearest forested area. Data were crosschecked to exclude any duplicate records. We collected I. typographus presences from 1973 to 2013 ( $n=1260$ unique records) and excluded occurrence points separated by a threshold distance of $50 \mathrm{~km}$ using SDMtoolbox v. 2.4 in ArcMap v. 10.5.1 [39]. Spatial filtering is typically used in species distribution models to account for sampling biases arising from clustered nature of species occurrence records [40]. We also reasoned that this threshold distance would reduce dispersal-induced correlations among points. Dispersal of I. typographus usually occurs over short distances of $<500 \mathrm{~m}$ [41,42], although a small proportion of beetles can passively disperse in wind currents ranging from a few kilometers

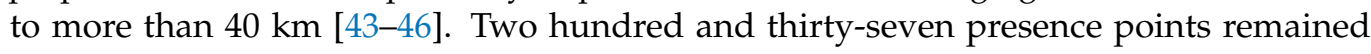
after the spatial rarefication. Pseudo-absence points $(n=10,000)$ were generated within the range of Norway spruce and Siberian spruce [47] (European Forest Genetic Resources Programme, 2009; www.euforgen.org [accessed on 2 December 2021]) in Eurasia prior to I. typographus model building, and spatially thinned so the distance between the points was at least $50 \mathrm{~km}$.

For E. polonica, we did not use the occurrence points of its main vector I. typographus where the pathogen was not positively identified such as via culture-based techniques, DNA assays, etc., as the association of E. polonica with I. typographus varies across its native range in Europe [25]. For instance, in some locations E. polonica is consistently associated with I. typographus [48,49], whereas in some others the association is sporadic [31], rare [50-53], or sometimes entirely absent ([54], as cited in [48]). In total, 149 occurrence records of E. polonica (112 presences and 37 true absences) were collected between the years 1973 and 2013 (Figure S1). After exclusion of duplicates, the occurrence data were spatially filtered at $50 \mathrm{~km}$ resolution such that 45 presence points and 16 absence points remained for model building. Ten thousand pseudo-absences were separately generated within the Norway spruce and Siberian spruce range in Eurasia prior to E. polonica model building. We spatially filtered the pseudo-absences to keep a minimum distance of $50 \mathrm{~km}$ among points. Then, we randomly selected pseudo-absences that were at least two decimal degrees away from E. polonica and I. typographus presence points. A simulation study previously showed that the ' $2{ }^{\circ}$ far' $^{\prime}$ approach could improve model performances when fewer presence records are available [55], which was the case with E. polonica.

\subsection{Climate Data}

A significant body of evidence suggests that climate plays an important role in biology, ecology, and landscape-level population dynamics of I. typographus. For instance, temperature influences the development rate, phenology (e.g., spring swarming), winter survival, diapause, and voltinism in I. typographus [56-59]. Low precipitation and drought-like conditions could predispose trees to I. typographus infestations [60,61], although magnitude of impacts may vary by location [62]. We restricted our modelling efforts to climate-based variables that would directly affect the beetle development. Although other factors such as 
tree or stand characteristics and soil conditions are important factors driving I. typographus population dynamics in its native Norway spruce range in Eurasia, their applicability to novel habitats and novel hosts is not relevant due to unknown relationships. Our exploratory model runs indicated that elevation, hillshade (a measure of illumination), and annual heat-moisture index were not significant predictors of $I$. typographus presences (Table S2).

We downloaded long-term averages of bioclimatic variables (https: / / www.worldclim. $\mathrm{org} /$; [accessed on 2 December 2021]) at a $10 \mathrm{~min}$ spatial resolution $\left(0.167^{\circ} \times 0.167^{\circ}\right)$ for the time periods 1970-2000 (which we henceforth refer to as the 'current' time period) and for 2021-2040, 2041-2060, 2061-2080, and 2081-2100. For future climates, three global climate models were used: CanESM5 [63], CNRM-ESM2-1 [64], and MIROC-ES2L [65]. The projections of future climates were based on estimations of greenhouse gas concentrations given multiple socio-economic pathways ('Shared Socio-economic Pathway', SSP). We chose two scenarios for future climates, SSP2-4.5 ('middle of the road' scenario) that projects moderate increases in global mean temperature and SSP5-8.5 ('high fossil-fuel development' scenario) that projects high temperature increases by the end of the 21st century [66]. The climate data were aggregated to a resolution of $0.5^{\circ} \times 0.5^{\circ}$ prior to model development. Model overfitting is a concern when using a large set of variables, especially when it potentially includes irrelevant variables. Therefore, for I. typographus climate-based modelling, 16 bioclimatic variables out of 19 were excluded after accounting for high pairwise correlations ( $\mathrm{r}>10.7$ I, Figure S2) and high variation inflation factor (VIF) scores $(>4)$. Three non-collinear variables that were retained include isothermality [67]:

$\left(\frac{\sum_{i=1}^{i=12}\left(\operatorname{Tmax}_{i}-\operatorname{Tmin}_{i}\right)}{12} /\left[\max \left(\left\{\operatorname{Tmax}_{1}, \cdots, \operatorname{Tmax}_{12}\right\}\right)-\min \left(\left\{\operatorname{Tmin}_{1}, \cdots, \operatorname{Tmin}_{12}\right\}\right)\right]\right) \times 100$

(BIO3; a measure of average monthly temperature variability compared with the annual temperature range); maximum temperature of warmest month (in ${ }^{\circ} \mathrm{C}$; $\mathrm{BIO} 5$ ), and mean temperature of driest quarter (in ${ }^{\circ} \mathrm{C}$, BIO9). Isothermality and mean temperature of driest quarter were strong predictors of I. typographus presences according to exploratory model runs (Table S2).

There is a paucity of relevant information in the research literature regarding links between climate and stand or landscape-scale distribution patterns of E. polonica. Laboratorybased assays, however, indicate that temperature influences growth rates of E. polonica. Optimal growth is observed at $20-25^{\circ} \mathrm{C}$, while lower $\left(10^{\circ} \mathrm{C}\right)$ or higher $\left(30^{\circ} \mathrm{C}\right)$ temperatures are less favorable for E. polonica [68]. Low temperatures have been shown to strongly inhibit fungal growth in related systems [69-71]. For model development, after accounting for pairwise correlations (Figure S3), we considered one variable, mean temperature of coldest quarter (BIO11), as the explanatory variable because it was consistently the strongest predictor of E. polonica among different variables tested (e.g., Table S3).

\subsection{Modelling}

Distributions of I. typographus were associated with climate variables using seven different modeling algorithms. These were generalized linear model (GLM), generalized additive model (GAM), classification tree analysis (CTA), artificial neural network (ANN), generalized boosting model (GBM), random forest (RF), and surface range envelope (SRE) via the Biomod2 package in R v. 4.0.4 [72,73]. We combined the occurrence records of $I$. typographus with the pseudo-absences and used the 'checkerboard1' method [74] to produce two presumably independent datasets, one for 'internal validation' (i.e., calibration and testing), and another for evaluating the models. Calibration and testing data ('calibration data') included 130 I. typographus presences and 1362 pseudo-absences. We randomly selected 10 separate pseudo-absence sets of 130 observations each from the above larger pseudo-absence set during model calibration. We found that this combination improved model performances compared with higher number of pseudo-absences in exploratory runs. The evaluation data comprised 107 presences and 1294 pseudo-absences, out of which 107 pseudo-absences were randomly selected for model evaluations. During model 
building, $70 \%$ of the calibration data were used to train the models, and the rest of the $30 \%$ was used for testing, and this process was repeated three times per pseudo-absence set. All the models were then assessed on the evaluation data, and the performance was determined.

For E. polonica, we used three modeling algorithms: GLM, CTA, and SRE, as we encountered computational problems with the other models. After $50 \mathrm{~km}$ spatial rarefication, 2495 pseudo-absences remained, including seven 'true' absence records. $(n=7)$. The true absences of E. polonica may be considered pseudo-absences at the coarse scale due to the spatially confined nature (i.e., tree-level) of sampling. We added true presence records $(n=45)$ of E. polonica to each of the 20 different random sets of 45 pseudo-absences that were extracted from the original pseudo-absence set. No separate evaluation data was set aside as the number of occurrence records were low. A threefold internal cross-validation was used on split samples (70\% calibration and 30\% testing) for a total of 180 individual models.

A commonly used performance metric in species distribution modelling, true skill statistic (TSS; true positive rate + true negative rate -1 ), was used for model assessment. The TSS values range from 0 to 1 , with values close to 1 indicating excellent model performance. A joint test of all pairwise contrasts and least squares means comparisons of model TSS scores by data type (testing, evaluation; as applicable) for each species were performed, respectively, using the emmeans and multcomp packages in $\mathrm{R}[75,76]$. Variable importance scores, which indicate the influence of a predictor on the model [73], were also computed for I. typographus. We used high performing, individual models (TSS >0.8) for ensemble modelling [77] via the committee averaging method [73] at each cross-validation run and pseudo-absence dataset. Two types of predictions can be outputted through the committee averaging method in Biomod2: an ensemble prediction (in this case, per crossvalidation run and pseudo-absence dataset) can be (1) an average of binary predictions from each of the individual models and (2) a single consensus binary prediction ( 0 or 1 ). For I. typographus, the former method was used, wherein predictions from 26 ensemble models were averaged to calculate the climatic suitability score (presented on a 0-100 scale). For E. polonica, the latter was used, where we calculated the most frequent (mode) of the consensus binary predictions from 49 ensemble models to generate a binary suitability map (0 or 1 ) for Canada and the United States. We clipped the prediction maps to the range of five key spruce species native to North America: black spruce, Picea mariana (Mill.) Britton, Sterns \& Poggenburg; white spruce, Picea glauca (Moench) Voss; Engelmann spruce, Picea engelmannii Parry ex Engelm.; Sitka spruce, Picea sitchensis (Bong.) Carr.; and red spruce, Picea rubens Sarg., on the basis of digitized tree range maps of Elbert L. Little, Jr. [78]. Finally, we overlaid the climatically suitable area polygon (i.e., $1^{\prime}$ s) for E. polonica over $I$. typographus climatic suitability map (QGIS v. 3.8.2-Zanzibar; latest version available at https: / / qgis.org/en/site/ [accessed on 2 December 2021]) to identify mutually conducive habitats for both species.

\section{Results}

\subsection{Models for Ips typographus}

Significant differences in mean TSS scores were observed among the individual models for both the testing data $(\mathrm{F}=30.19, p<0.0001)$ and the evaluation data for I. typographus $(\mathrm{F}=170.66, p<0.0001)$ according to a separate joint test of all pairwise comparisons for each dataset. Ensemble models, GLM, GAM, ANN, GBM, and RF models had similar mean TSS scores (for testing data) that differed significantly from the mean TSS scores of CTA and SRE models (Figure 1). For the evaluation data, mean TSS score was the highest for the ensemble model, but this did not differ from CTA, ANN, and RF models (Figure 1). Lowest mean TSS value was observed for the SRE model. 


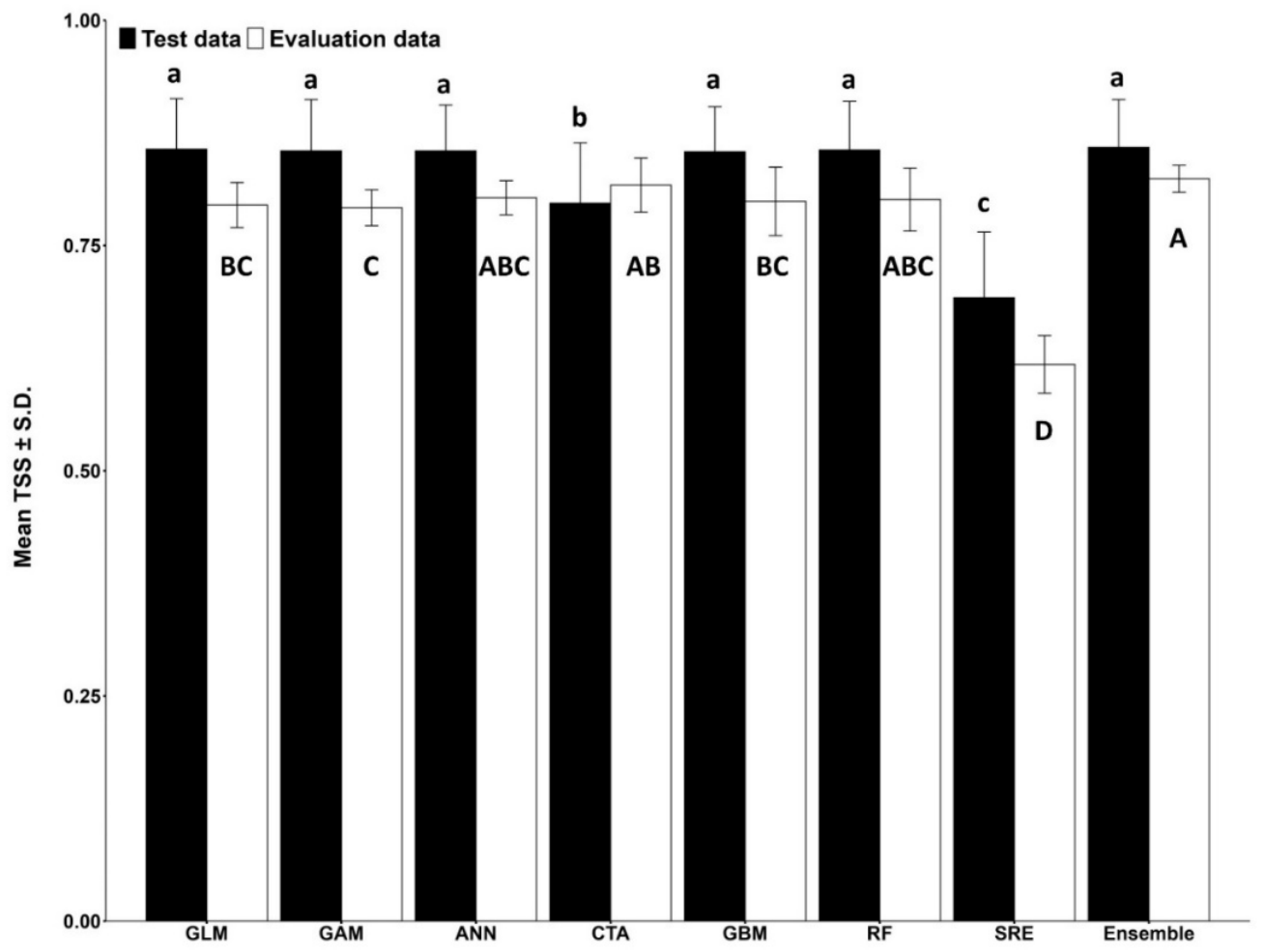

Figure 1. Mean TSS $( \pm$ S.D.) scores of individual $(n=30)$ and ensemble models $(n=26)$ for predicting I. typographus presences using testing and evaluation data. GLM: generalized linear model, GAM: generalized additive model, ANN: artificial neural network, CTA: classification tree analysis, GBM: generalized boosting model, RF: random forest, SRE: surface range envelope. Bars with the same uppercase (white bars) or lowercase (black bars) letter are not significantly different according to multiple pairwise comparisons $(p<0.05)$.

Using the GLM model as a template, we show in Figure 2 the plots of mean probability of I. typographus presence, across the different cross-validation runs and pseudo-absence sets, in comparison with the predictor variables. A strong relationship between isothermality and mean temperature of driest quarter was observed for I. typographus. Maximum temperature of warmest month had a negative relationship with the probability of $I$. $t y-$ pographus presence at temperatures $>20^{\circ} \mathrm{C}$, although progressively high variability in predicted probabilities was observed at these temperatures (Figure 2). Mean temperature of driest quarter, isothermality, and maximum temperature of warmest month, in that order, were important variables in predicting I. typographus occurrences (Figure 3). 


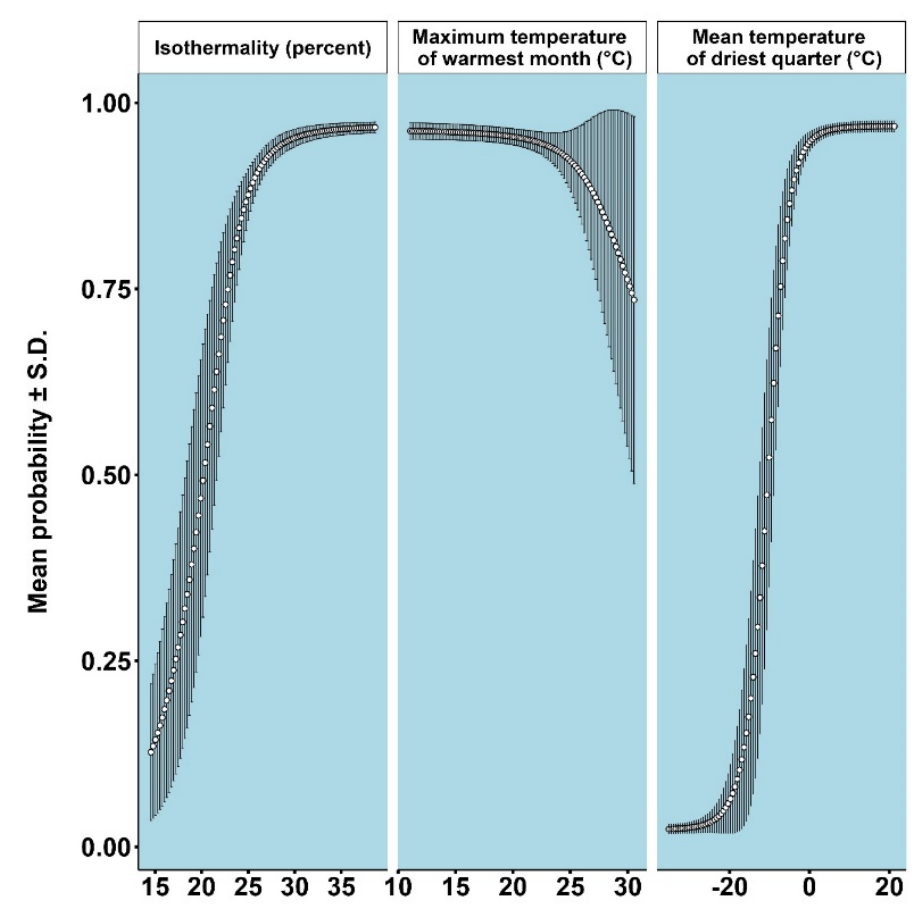

Figure 2. Mean probability \pm S.D. of I. typographus presence at different values of the explanatory variable according to generalized linear models $(n=30$ per point).

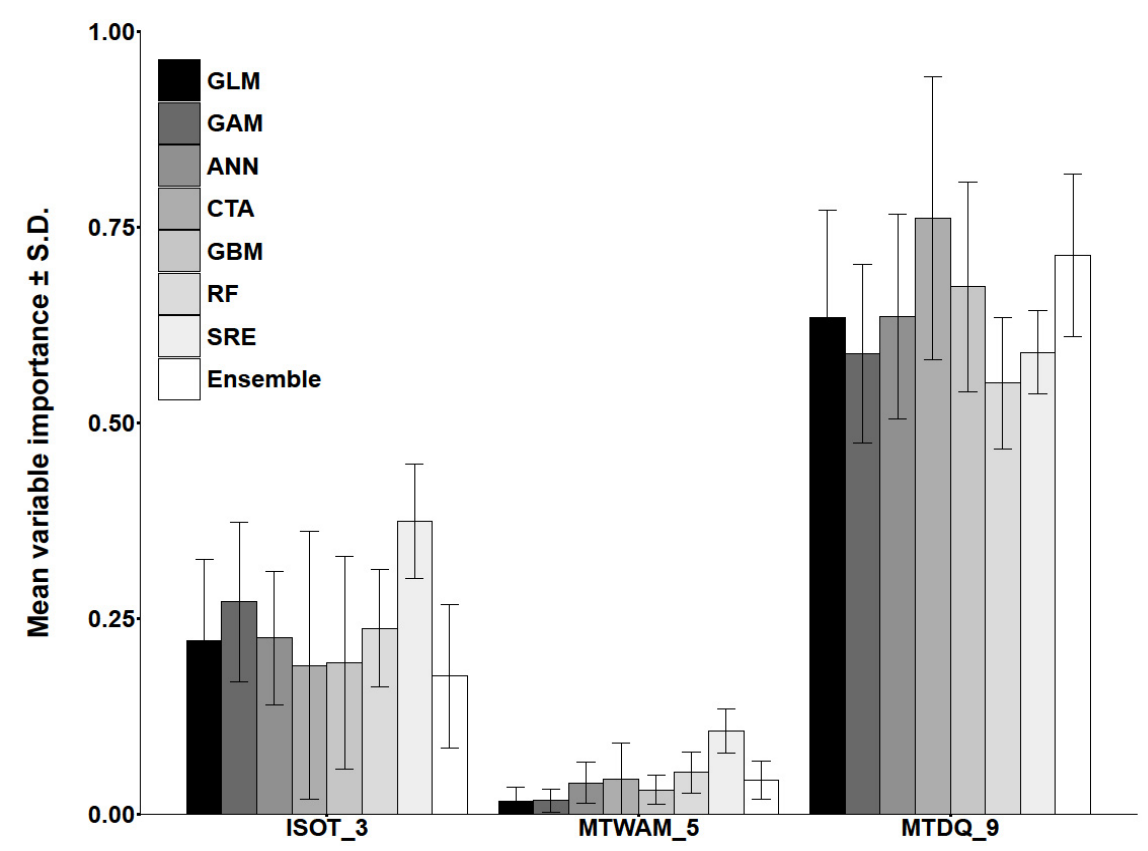

Figure 3. Variable importance scores for predictors used in models for Ips typographus. ISOT_3: isothermality, MTWAM_5: maximum temperature of warmest month, MTDQ_9: mean temperature of driest quarter. GLM: generalized linear model, GAM: generalized additive model, ANN: artificial neural network, CTA: classification tree analysis, GBM: generalized boosting model, RF: random forest, SRE: surface range envelope.

\subsection{Models for Endoconidiophora polonica}

Mean TSS scores differed significantly among models according to a joint test of all pairwise comparisons ( $\mathrm{F}=45.371, p<0.0001)$. Ensemble and GLM models showed higher TSS scores than CTA and SRE models (Figure 4). A plot of mean probability of E. polonica presence and mean temperature of coldest quarter using the GLM models showed that 
temperatures warmer than $-20{ }^{\circ} \mathrm{C}$ in the coldest quarter increased the probability of $E$. polonica presence (Figure 5).

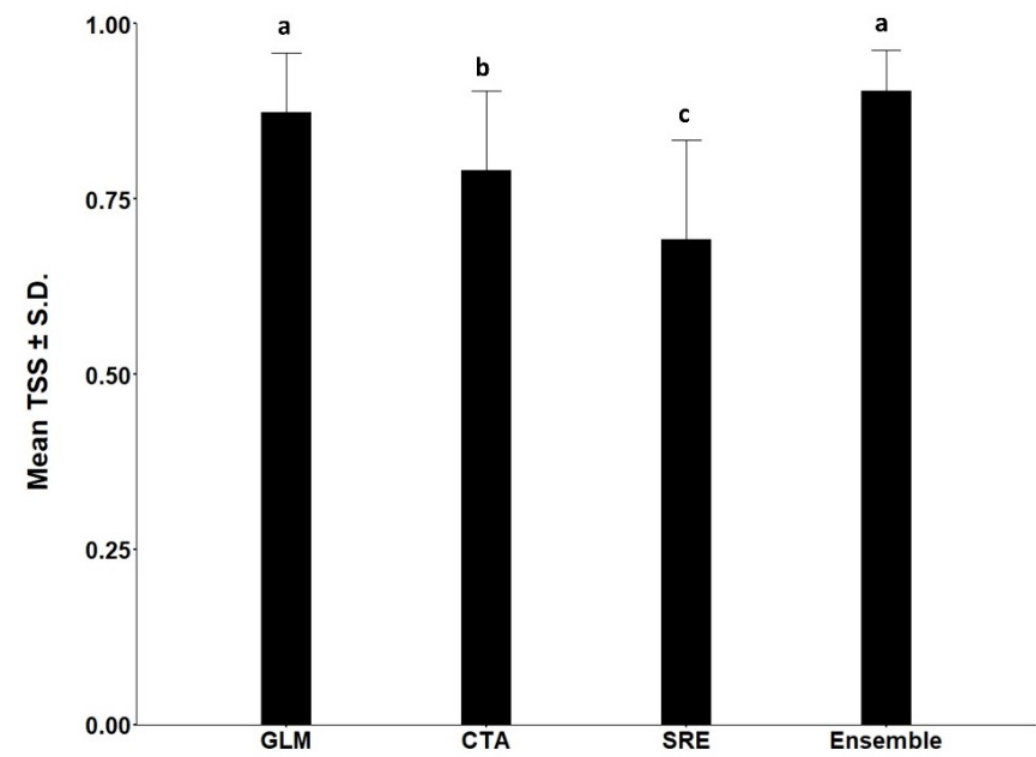

Figure 4. Mean TSS ( \pm S.D.) scores of individual $(n=60)$ and ensemble models $(n=49)$ for predicting E. polonica presences. GLM: generalized linear model, CTA: classification tree analysis, SRE: surface range envelope. Bars with the same letter are not significantly different according to multiple pairwise comparisons $(p<0.05)$.

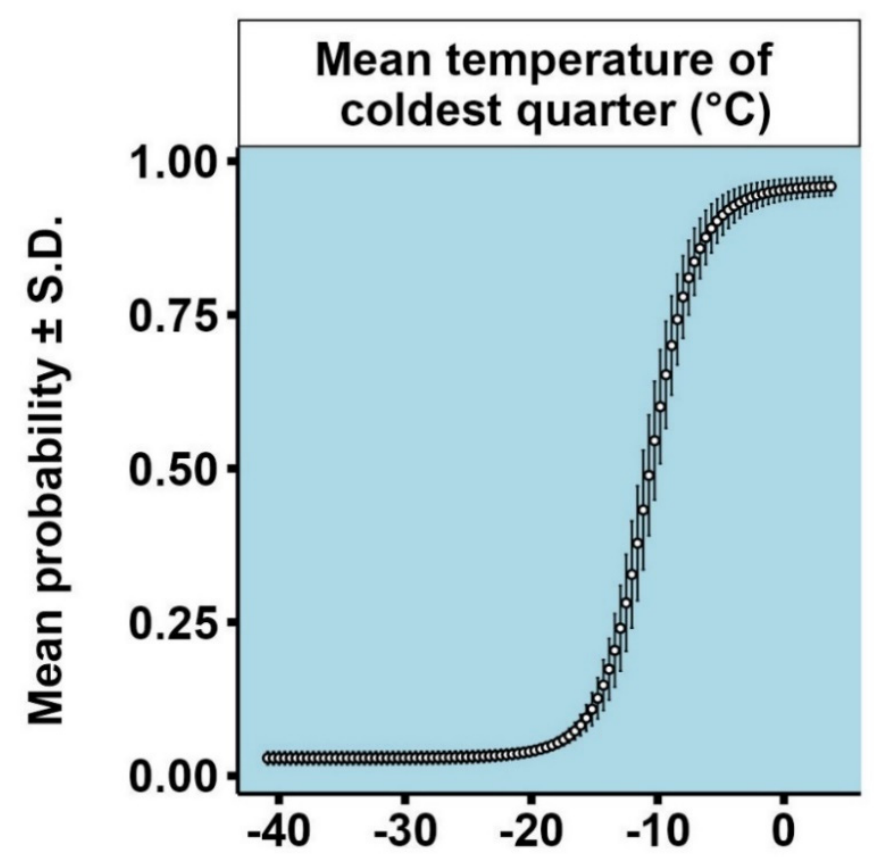

Figure 5. Mean probability \pm S.D. of E. polonica presence at different values of the explanatory variable according to generalized linear models ( $n=60$ per point).

3.3. Climatically Suitable Regions for I. typographus and E. polonica in Canada and the United States

Climatically suitable regions for I. typographus according to the ensemble model showed that British Columbia, western Alberta, southern Yukon, and Newfoundland and Labrador in Canada are suitable under current conditions for I. typographus (Figure 6). Similarly, spruce habitats throughout the United States, except northern Alaska, Minnesota, 
western Wisconsin, and parts of northeastern United States, are suitable for I. typographus (Figure 6). Regions of climatic suitability for E. polonica mostly overlap those of I. typographus, except the northern limits of the beetle's conducive zone in North America. Over the coming decades in SSP2-4.5 scenario, I. typographus climatic suitability will improve in northwestern and eastern North America. Although regions of overlapping suitability for the insect and the pathogen will increase in North America by the end of the 21st century under SSP2-4.5, the northernmost suitable regions for the insect will be unfavorable for the fungus (Figure 7). Similar to SSP2-4.5, northwestern and eastern North America will see increased suitability for both I. typographus and E. polonica when compared with the 1970-2000 reference period under SSP5-8.5 scenario (Figure 7). Eastern Canada will in particular see increases in climatic suitability under SSP5-8.5 for I. typographus, and this region will be likewise suitable for the fungus. Although climatic mismatches will occur in the northern portions of I. typographus conducive zones in eastern Canada, they will largely decline from 2021-2040 to 2080-2100. However, inconsistencies in overlapping suitable regions will continue to be observed in northernmost portions of western North America under SSP5-8.5 toward the end of this century. Other, more southern spruce habitats of western North America will remain suitable for both species under SSP2-4.5 and SSP5-8.5 (Figure 7). Portions of the boreal forest in Saskatchewan and Manitoba, Canada, will become suitable for I. typographus and E. polonica after 2060 under higher temperature regimes of SSP5-8.5, creating a coast-to-coast corridor of climatic suitability for both species in Canada.

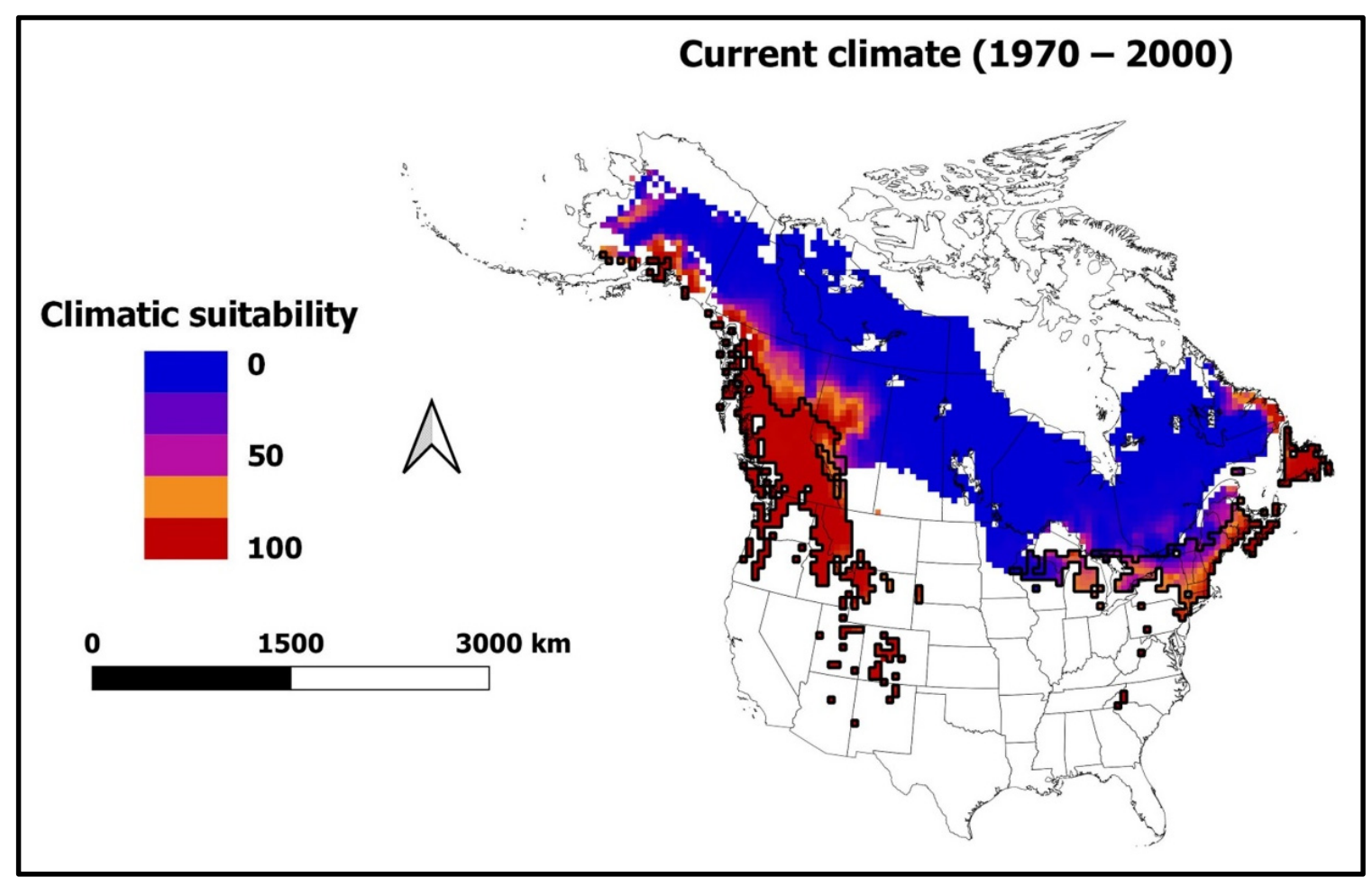

Figure 6. Climatic suitability of spruce forests in Canada and the United States for Ips typographus during the current period (1970-2000). Thick black line overlapping the I. typographus map represents climatically suitable area for Endoconidiophora polonica. 


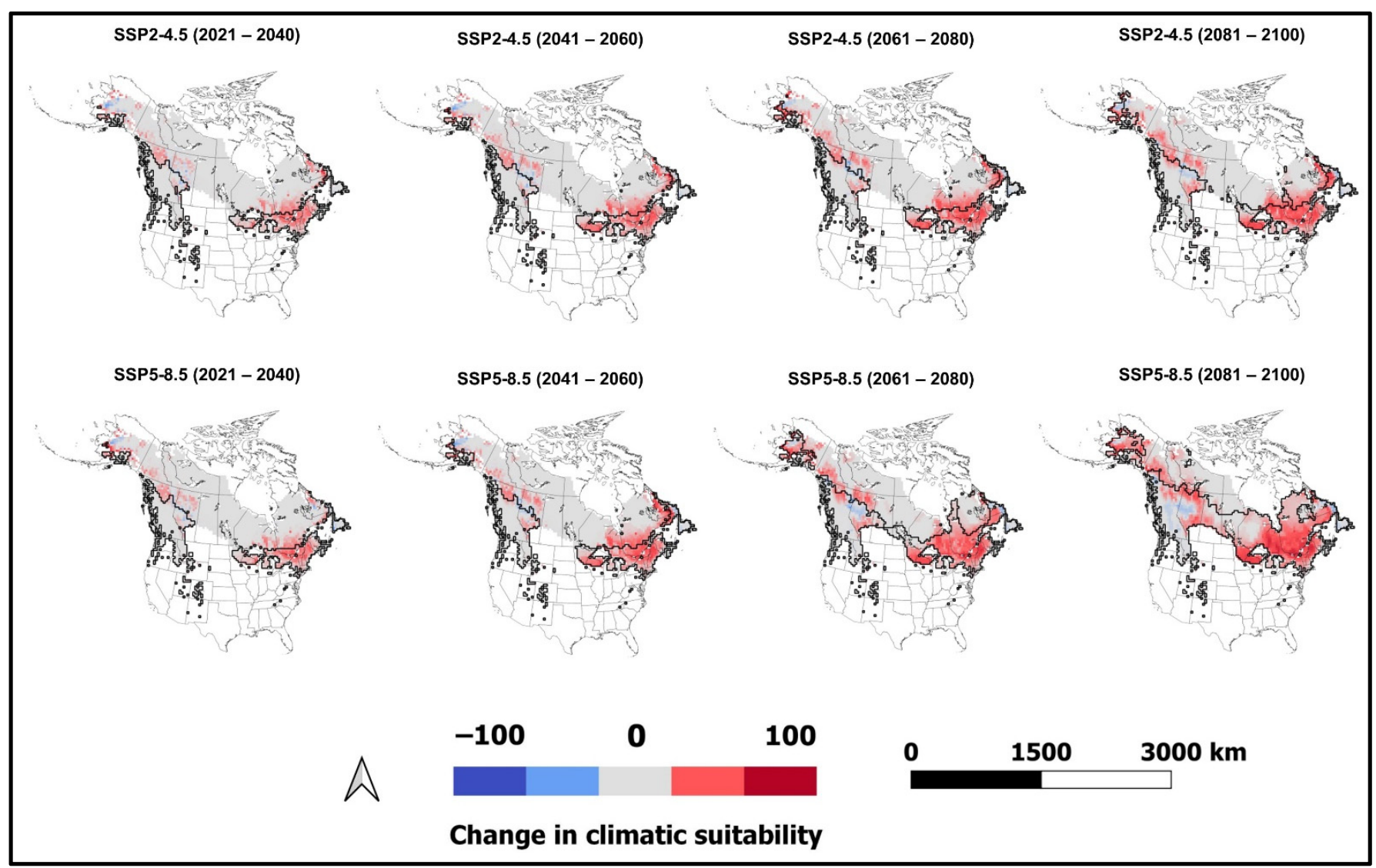

Figure 7. Maps of changes in climatic suitability for Ips typographus during four future periods (2021-2040, 2041-2060, 2061-2080, and 2081-2100) with respect to the current period (1970-2000), clipped to the spruce range in Canada and the United States. Thick black lines overlapping the I. typographus maps represent climatically suitable areas for Endoconidiophora polonica. SSP2-4.5 and SSP5-8.5 are shared socio-economic pathway (SSP) scenarios that project moderate $\left(2.6^{\circ} \mathrm{C}\right)$ and high $\left(5^{\circ} \mathrm{C}\right)$ global mean temperature increases by the end of the 21 st century, respectively.

\section{Discussion}

Establishment of a non-native species in a novel habitat is a complex process involving multiple positive and negative feedback that determine whether the population will persist or will go extinct $[14,79,80]$. Different factors such as propagule pressure (the number of introductory events as well as the initial population size), spatial patterns of introductions, temporal consistency in introduction events, location-specific characteristics (e.g., availability of susceptible hosts), species traits, demographic factors (Allee effects), and environmental conditions influence the establishment success of a non-native species in a new location [81]. Interestingly, in the case of I. typographus, an intriguing aspect concerning its potential establishment in North America is that despite repeated interceptions at ports of entry in the United States and Canada over the past several decades, and possible escapes into the wild, there have been no reports of successful establishment. It is likely that one or a combination of the above-mentioned factors governing invasive species establishment could have prevented I. typographus founding populations in North America or the insect might have escaped detection thus far. However, in the long term, climate per se does not appear to be a hindrance to the establishment of I. typographus in North America.

Our results provide strong evidence that climates are currently conducive or will become conducive in the future decades in previously unfavorable areas for the potential establishment of I. typographus and the associated blue stain fungal pathogen E. polonica in Canada and the United States. Boreal forests in eastern prairie provinces (Saskatchewan and Manitoba) of Canada will only become suitable at the end of the century if high temperatures as projected under SSP5-8.5 scenario were to occur. In comparison, using a 
phenology model of I. typographus, Bentz et al. [33] showed that extensive regions of spruce forests in North America support a univoltine life cycle of I. typographus. They found that a second generation is very likely in large tracts of spruce forests in North America including the lower and middle boreal region in Canada by the end of the 21st century. Our findings are consistent with those of Bentz et al. [33] with regard to northeastern and western North America under the high temperature scenarios (RCP8.5 and SSP5-8.5). Variations in projected climatic suitability (e.g., in central Canada) between our studies can be attributed to the different approaches used (process-based vs. our correlative niche modeling). Although there are advantages and limitations of both of these approaches [37], outputs from multiple different approaches provide complementary information that would facilitate decision making, potentially including additional screening and policy measures to prevent the introduction of these exotic species into North America. This is all the more important in the face of climate change, whose impact on forest ecosystems will be far reaching $[82,83]$.

There is an ample body of evidence that suggests that climate plays an important role in the distribution, survival, and mortality patterns of a wide variety of species in different ecosystems [84-86]. Forests, in particular, are vulnerable to changes in climate (e.g., increased temperatures and multiyear droughts) both directly via influences on tree physiology and indirectly through increased activity of disturbance agents such as certain insects and pathogens $[21,87,88]$. Population and range dynamics of forest insects, particularly bark beetles such as I. typographus [59] and the mountain pine beetle (Dendroctonus ponderosae Hopkins) [89], are directly influenced by increasing temperatures. In the case of forest diseases, the influence of climate is more complex as diseases caused by biotic agents are a consequence of a combination of a virulent pathogen, conducive environment, and susceptible host species ('disease triangle'). When sufficient empirical information on the ecology of a disease is available, such as whether temperature and precipitation directly affect the pathogen development and spread or whether their influences on disease development are mediated through host stress, some general trends may be expected under future climates [90]. For example, warmer temperatures and wetter conditions could aggravate the impacts of certain forest diseases such as Dothistroma needle blight of pines, whereas for some other diseases such as Armillaria root disease, warmer and drier conditions could increase the disease impacts via increased host stress.

Ours is the only study to our knowledge that used correlative niche modeling to map the climatic suitability of a harmful bark beetle species (I. typographus) and an associated, virulent blue stain fungal pathogen (E. polonica). Such studies are surprisingly rare, probably because in these systems, the pathogen aspect receives comparatively less attention in terms of landscape ecology than the insect aspect. For instance, little quantitative analysis of influence of weather conditions on the biology, ecology, and distributions of E. polonica has been undertaken to date. In contrast, abiotic influences on population and range dynamics of I. typographus have been well studied $[59,60,91]$. In this study, mean temperature of driest quarter was the most important predictor of I. typographus presence, followed by monthly temperature fluctuations with respect to annual temperature extremes (isothermality), and maximum temperature of warmest month. For E. polonica, winter temperatures were a limiting factor. Other factors such as the population dynamics of I. typographus and seasonal weather patterns [92] could potentially influence the spatio-temporal distributions of $E$. polonica over the landscape.

We accounted for multiple uncertainties and biases in this study including those resulting from (a) the use of any particular model (by using multiple models in an ensemble framework), (b) spatial dependence (due to clustering of observations), (c) multicollinearity among predictors (in the case of I. typographus), (d) pseudo-absence selections, (e) climate models (ensemble mean of three GCMs used), and (f) climate change scenarios (SSP2-4.5 and SSP5-8.5). Nonetheless, there are certain caveats to our analyses. First, although we intensively surveyed the literature and online databases for occurrence data of both species (1973-2013), we might have missed some occurrence records, especially those published 
in the non-English scientific literature. Ips typographus records were more comprehensive than E. polonica, and therefore it is possible that E. polonica actual distribution is more widespread than what our collected records suggest (e.g., due to sampling inadequacy). Nevertheless, given the association between I. typographus and E. polonica, the projected climatically suitable areas for I. typographus in Canada and the United States can be thought of as the maximum potential suitable range for E. polonica, if it is assumed that all areas where I. typographus was found in Eurasia is also co-habited by E. polonica. Second, we used long-term climate averages in developing our models; however, long-term means may mask short-term weather fluctuations that could be important in accurately determining climatic suitability of a given location. Finally, the extents of climatically suitable habitats for these species in Canada and the United States does not necessarily translate into probable future distributions due to multiple reasons such as variability in species traits in new environments (e.g., diapause), altered species-environment relationships, maladaptation, dispersal limitations, competing species, and range shifts of trees. Despite these limitations and uncertainties, this study improves our knowledge regarding climate-based establishment potential of I. typographus and E. polonica in Canada and the United States. Our work provides valuable insights into regions of overlapping climatic suitability that may be at a heightened risk of damage by the two study species under future climates, as well as helpful information necessary for targeted management interventions in case of an introduction. Interestingly, conifer forests in western North America that are projected to be highly suitable for I. typographus regularly experience outbreaks of two native bark beetle species, D. ponderosae, which attacks pine trees (Pinus spp.), and spruce beetle, D. rufipennis (Kirby), which infests spruce trees (Picea spp.). Ips typographus is attracted to spruce colonized by fungal associates of D. rufipennis; thus, if introduced into North America, $I$. typographus may benefit from this preference [29]. Should exceptional conditions arise in the future where aggressive native bark beetles co-occur with I. typographus, catastrophic forest damage is possible. Thus, our study indirectly also alludes to the continued necessity of careful monitoring and management of native bark beetle populations in western North America.

\section{Conclusions}

We sought to determine the suitability of climates of Canada and the United States for potential establishment of the European spruce bark beetle, I. typographus, and the associated virulent blue-stain fungus, E. polonica. Our results suggest that spruce habitats in western Canada, in disparate pockets in eastern Canada, and throughout the United States are currently conducive for both species. Spatial mismatches in suitable zones between $I$. typographus and E. polonica will occur at the northernmost suitable locations throughout this century. The boreal forest in central Canada will become suitable for both species by the end of the century, although the extent of suitability will vary depending on the magnitude of warming. Although many external factors such as proximity and connectivity to ports of entry, propagule pressure, competition, species dispersal capacity, and presence of efficacious natural enemies dictate the eventual species establishment in a new location, our study provides initial insights into potential 'hot spots' for establishment of this insect vector-pathogen complex in North America.

Rising economic growth worldwide and climate change, combined with fast and efficient transport networks, have created opportunities for invasive species to gain a foothold in novel habitats. Identifying international high-risk transport corridors and consistent monitoring programs are therefore necessary in order to be well prepared for pre- and post-introduction of invasive species. Macroscale assessments of economically important, non-native forest insects associated with potentially virulent pathogens would benefit from a more integrated assessment of introduction risk, including combining pathway analysis with improved climate-based assessments, and from a more holistic research approach involving the vector insect, the fungal associates, and the environment, 
including impacts on novel tree hosts. Filling such information gaps will ultimately provide valuable decision-making resources for policymakers.

Supplementary Materials: The following are available online at https:/ /www.mdpi.com/article/10 .3390 /f12121725/s1, Figure S1: Spatial distribution of the European spruce bark beetle, Ips typographus L., and the associated blue-stain fungal pathogen, Endoconidiophora polonica, in Eurasia (1973-2013). Figure S2: Correlations among bioclimatic variables extracted from occurrence data (presence and pseudo-absence data) of Ips typographus. Black squares indicate $\varrho<|0.70|$. Figure S3: Correlations among bioclimatic variables extracted from occurrence data (presence and pseudo-absence data) of Endoconidiophora polonica. Black squares indicate $\varrho<|0.70|$. Table S1: A non-exhaustive list of primary or potential host tree species, and their distributions, of the European spruce bark beetle (Ips typographus) and the associated blue stain fungal pathogen Endoconidiophora polonica. Table S2: A generalized linear model associating climatic and topographic variables with occurrences of Ips typographus in Eurasia $\left(\mathrm{n}_{\text {presences }}=237 ; \mathrm{n}_{\text {pseudo-absences }}=237\right)$. Table S3: A generalized linear model associating climatic and topographic variables with occurrences of Endoconidiophora polonica in Eurasia $\left(\mathrm{n}_{\text {presences }}=45 ; \mathrm{n}_{\text {pseudo-absences }}=45\right)$.

Author Contributions: Conceptualization, methodology, formal analysis, investigation, funding acquisition, K.R.S.; data curation, C.C.; writing—original draft preparation, K.R.S.; writing—review and editing, K.R.S., C.C. All authors have read and agreed to the published version of the manuscript.

Funding: This work was funded by Natural Resource Canada's Forest Invasive Alien Species (FIAS) program.

Data Availability Statement: Climate datasets used in this study are available in the public domain at https:/ / www.worldclim.org/data/index.html [accessed on 2 December 2021].

Acknowledgments: We thank Benoit Filion and Rémi Saint-Amant for project assistance. Thanks also to Naomie Herpin-Saunier for reviewing an earlier draft of this manuscript. We greatly appreciate comments by two anonymous reviewers that helped improve the manuscript. We acknowledge the World Climate Research Programme, which, through its Working Group on Coupled Modelling, coordinated and promoted CMIP6; the climate modeling groups for producing and making available their model output; the Earth System Grid Federation (ESGF) for archiving the data and providing access; and the multiple funding agencies who support CMIP6 and ESGF.

Conflicts of Interest: The authors declare no conflict of interest. The funders had no role in the design of the study; in the collection, analyses, or interpretation of data; in the writing of the manuscript; or in the decision to publish the results.

\section{References}

1. Orwig, D.A. Ecosystem to regional impacts of introduced pests and pathogens: Historical context, questions and issues. $J$. Biogeogr. 2002, 29, 1471-1474. [CrossRef]

2. Lovett, G.M.; Canham, C.D.; Arthur, M.A.; Weathers, K.C.; Fitzhugh, R.D. Forest ecosystem responses to exotic pests and pathogens in eastern North America. Bioscience 2006, 56, 395-405. [CrossRef]

3. Allen, E.A.; Humble, L.M. Nonindigenous species introductions: A threat to Canada's forests and forest economy. Can. J. Plant Pathol. 2002, 24, 103-110. [CrossRef]

4. $\quad$ Aukema, J.E.; Leung, B.; Kovacs, K.; Chivers, C.; Britton, K.O.; Englin, J.; Frankel, S.J; Haight, R.G.; Holmes, T.P.; Liebhold, A.M.; et al. Economic impacts of non-native forest insects in the continental United States. PLoS ONE 2011, 6, e24587. [CrossRef]

5. Haack, R.A. Intercepted Scolytidae (Coleoptera) at U.S. ports of entry: 1985-2000. Integr. Pest Manag. Rev. 2001, 6, $253-282$. [CrossRef]

6. Haack, R.A. Exotic bark-and wood-boring Coleoptera in the United States: Recent establishments and interceptions. Can. J. For. Res. 2006, 36, 269-288. [CrossRef]

7. Humble, L.; Allen, E. Forest biosecurity: Alien invasive species and vectored organisms. Can. J. Plant Pathol. 2006, 28, S256-S269. [CrossRef]

8. Liebhold, A.M.; Brockerhoff, E.G.; Garrett, L.J; Parke, J.L.; Britton, K.O. Live plant imports: The major pathway for forest insect and pathogen invasions of the US. Front. Ecol. Environ. 2012, 10, 135-143. [CrossRef]

9. Colautti, R.I.; Bailey, S.A.; Van Overdijk, C.D.A.; Amundsen, K.; MacIsaac, H.J. Characterised and projected costs of nonindigenous species in Canada. Biol. Invasions 2006, 8, 45-59. [CrossRef]

10. Kovacs, K.; Václavík, T.; Haight, R.G.; Pang, A.; Cunniffe, N.J.; Gilligan, C.A.; Meentemeyer, R.K. Predicting the economic costs and property value losses attributed to sudden oak death damage in California (2010-2020). J. Environ. Manag. 2011, 92, 1292-1302. [CrossRef] 
11. Haight, R.G.; Homans, F.R.; Horie, T.; Mehta, S.V.; Smith, D.J.; Venette, R.C. Assessing the cost of an invasive forest pathogen: A case study with oak wilt. Environ. Manag. 2011, 47, 506-517. [CrossRef]

12. Anagnostakis, S.L. Chestnut blight: The classical problem of an introduced pathogen. Mycologia 1987, 79, 23-37. [CrossRef]

13. Evans, A.M. The speed of invasion: Rates of spread for thirteen exotic forest insects and diseases. Forests 2016, 7, 99. [CrossRef]

14. Prospero, S.; Cleary, M. Effects of host variability on the spread of invasive forest diseases. Forests 2017, 8, 80. [CrossRef]

15. Lovett, G.M.; Weiss, M.; Liebhold, A.M.; Holmes, T.P.; Leung, B.; Lambert, K.F.; Orwig, D.A.; Campbell, F.T.; Rosenthal, J.; McCullough, D.J.; et al. Nonnative forest insects and pathogens in the United States: Impacts and policy options. Ecol. Appl. 2016, 26, 1437-1455. [CrossRef] [PubMed]

16. Nealis, V.G.; Demerchant, I.; Langor, D.; Noseworthy, M.K.; Pohl, G.; Porter, K.; Shanks, E.; Turnquist, R.; Waring, V. Historical occurrence of alien arthropods and pathogens on trees in Canada. Can. J. For. Res. 2015, 46, 172-180. [CrossRef]

17. Liebhold, A.M.; Turner, R.M.; Blake, R.E.; Bertelsmeier, C.; Brockerhoff, E.G.; Nahrung, H.F.; Pureswaran, D.S.; Roques, A.; Seebens, H.; Yamanaka, T. Invasion disharmony in the global biogeography of native and non-native beetle species. Divers. Distrib. 2021, 27, 2050-2062. [CrossRef]

18. Poland, T.M.; McCullough, D.G. Emerald ash borer: Invasion of the urban forest and the threat to North America's ash resource. J. For. 2006, 104, 118-124.

19. Valenta, V.; Moser, D.; Kapeller, S.; Essl, F. A new forest pest in Europe: A review of emerald ash borer (Agrilus planipennis) invasion. J. Appl. Entomol. 2017, 141, 507-526. [CrossRef]

20. Rizzo, D.M.; Garbelotto, M.; Davidson, J.M.; Slaughter, G.W.; Koike, S.T. Phytophthora ramorum as the cause of extensive mortality of Quercus spp. and Lithocarpus densiflorus in California. Plant Dis. 2002, 86, 205-214. [CrossRef] [PubMed]

21. Dale, V.H.; Joyce, L.A.; McNulty, S.; Neilson, R.P.; Ayres, M.P.; Flannigan, M.D.; Hanson, P.J.; Irland, L.C.; Lugo, A.E.; Peterson, C.J.; et al. Climate change and forest disturbances. Bioscience 2001, 51, 723-734. [CrossRef]

22. Økland, B.; Erbilgin, N.; Skarpaas, O.; Christiansen, E.; Långström, B. Inter-species interactions and ecosystem effects of non-indigenous invasive and native tree-killing bark beetles. Biol. Invasions 2011, 13, 1151-1164. [CrossRef]

23. Flø, D.; Norli, H.R.; Økland, B.; Krokene, P. Successful reproduction and pheromone production by the spruce bark beetle in evolutionary naïve spruce hosts with familiar terpenoid defences. Agric. For. Entomol. 2018, 20, 476-486. [CrossRef]

24. de Beer, Z.W.; Duong, T.A.; Barnes, I.; Wingfield, B.D.; Wingfield, M.J. Redefining Ceratocystis and allied genera. Stud. Mycol. 2014, 79, 187-219. [CrossRef]

25. Kirisits, T. Fungal associates of European bark beetles with special emphasis on the ophiostomatoid fungi. In Bark and Wood Boring Insects in Living Trees in Europe, a Synthesis; Springer: Dordrecht, The Netherlands, 2007; pp. 181-236.

26. Krokene, P.; Solheim, H. Fungal associates of five bark-beetle species colonizing Norway spruce. Can. J. For. Res. 1996, 26, 2115-2122. [CrossRef]

27. Kirisits, T. Pathogenocity of three blue-stain fungi associated with the bark beetle lps typographus to Norway spruce in Austria. Österr. Z. Pilzk. 1998, 7, 191-201.

28. Krokene, P.; Solheim, H. Pathogenicity of four blue-stain fungi associated with aggressive and nonagressive bark beetles. Phytopathology 1998, 88, 39-44. [CrossRef]

29. Tanin, S.M.; Kandasamy, D.; Krokene, P. Fungal interactions and host tree preferences in the spruce bark beetle Ips typographus. Front. Microbiol. 2021, 12, 1375. [CrossRef]

30. Christiansen, E.; Solheim, H. The bark beetle-associated blue-stain fungus Ophiostoma polonicum can kill various spruces and Douglas fir. Eur. J. For. Pathol. 1990, 20, 436-446. [CrossRef]

31. Jankowiak, R.; Hilszczanski, J. Ophiostomatoid fungi associated with Ips typographus (L.) on Picea abies [(L.) H. Karst.] and Pinus sylvestris L. in north-eastern Poland. Acta Soc. Bot. Pol. 2005, 74, 345-350. [CrossRef]

32. Schroeder, M.; Cocoss, D. Performance of the tree-killing bark beetles Ips typographus and Pityogenes chalcographus in non-indigenous lodgepole pine and their historical host Norway spruce. Agric. For. Entomol. 2018, 20, 347-357. [CrossRef]

33. Bentz, B.J.; Jonsson, A.M.; Schroeder, M.; Weed, A.; Wilcke, R.A.I.; Larsson, K. Ips typographus and Dendroctonus ponderosae models project thermal suitability for intra- and inter-continental establishment in a changing climate. Front. For. Glob. Chang. 2019, 2, 1-17. [CrossRef]

34. Elith, J.; Leathwick, J.R. Species distribution models: Ecological explanation and prediction across space and time. Annu. Rev. Ecol. Evol. Syst. 2009, 40, 677-697. [CrossRef]

35. Guisan, A.; Zimmermann, N.E. Predictive habitat distribution models in ecology. Ecol. Model. 2000, 135, 147-186. [CrossRef]

36. Herpin-Saunier, N.Y.H.; Sambaraju, K.R.; Yin, X.; Feau, N.; Zeglen, S.; Ritóková, G.; Omdal, D.; Côté, C.; Hamelin, R.C. Genetic lineage distribution modelling to predict epidemics of a conifer disease. Front. For. Glob. Change 2021. In press.

37. Briscoe, N.J.; Elith, J.; Salguero-Gómez, R.; Lahoz-Monfort, J.J.; Camac, J.S.; Giljohann, K.M.; Holden, M.H.; Hradsky, B.A.; Kearney, M.R.; McMahon, S.M.; et al. Forecasting species range dynamics with process-explicit models: Matching methods to applications. Ecol. Lett. 2019, 22, 1940-1956. [CrossRef] [PubMed]

38. Ireland, K.B.; Kriticos, D.J. Why are plant pathogens under-represented in eco-climatic niche modelling? Int. J. Pest Manag. 2019, 65, 207-216. [CrossRef]

39. Brown, J.L. SDMtoolbox: A python-based GIS toolkit for landscape genetic, biogeographic and species distribution model analyses. Methods Ecol. Evol. 2014, 5, 694-700. [CrossRef] 
40. Reddy, S.; Dávalos, L.M. Geographical sampling bias and its implications for conservation priorities in Africa. J. Biogeogr. 2003, 30, 1719-1727. [CrossRef]

41. Wichmann, L.; Ravn, H.P. The spread of Ips typographus (L.) (Coleoptera, Scolytidae) attacks following heavy windthrow in Denmark analysed using GIS. For. Ecol. Manag. 2001, 148, 31-39. [CrossRef]

42. Zumr, V. Dispersal of the spruce bark beetle Ips typographus (L.) (Col., Scolytidae) in spruce woods. J. Appl. Entomol. 1992, 114, 348-352. [CrossRef]

43. Botterweg, P.F. Dispersal and flight behaviour of the spruce bark beetle Ips typographus in relation to sex, size and fat content. J. Appl. Entomol. 1982, 94, 466-489. [CrossRef]

44. Forsse, E.; Solbreck, C.H. Migration in the bark beetle Ips typographus L.: Duration, timing and height of flight. Z. Angew. Entomol. 1985, 100, 47-57. [CrossRef]

45. Nilssen, A. Long-range aerial dispersal of bark beetles and bark weevils (Coleoptera, Scolytidae and Curculionidae) in northern Finland [Ips typographus, Hylastes cunicularius, Dryocoetes autographus, Hylobius abietis]. Ann. Entomol. Fenn. 1984, 50, 37-42.

46. Weslien, J.; Lindelöw, Å. Recapture of marked spruce bark beetles (Ips typographus) in pheromone traps using area-wide mass trapping. Can. J. For. Res. 1990, 20, 1786-1790. [CrossRef]

47. Schmidt-Vogt, H. Monographie der Picea abies (L.) Karst. unter Berücksichtigung genetischer und züchterischer Aspekte. Forstwiss. Centralbl. 1978, 97, 281-302. [CrossRef]

48. Kirisits, T. Fungi isolated from Picea abies infested by the bark beetle Ips typographus in the Białowieża forest in north-eastern Poland. For. Pathol. 2010, 40, 100-110. [CrossRef]

49. Solheim, H. Fungal succession in sapwood of Norway spruce infested by the bark beetle Ips typographus. Eur. J. For. Path 1992, 22, 136-148. [CrossRef]

50. Jankowiak, R.; Kacprzyk, M.; Młynarczyk, M. Diversity of ophiostomatoid fungi associated with bark beetles (Coleoptera: Scolytidae) colonizing branches of Norway spruce (Picea abies) in southern Poland. Biologia 2009, 64, 1170-1177. [CrossRef]

51. Kirschner, R. Diversity of filamentous fungi in bark beetle galleries in central Europe. In Trichomycetes and Other Fungal Groups; Misra, J.K., Horn, B.W., Eds.; Science Publishers, Inc.: Plymouth, UK, 2001; pp. 175-196.

52. Sallé, A.; Monclus, R.; Yart, A.; Garcia, J.; Romary, P.; Lieutier, F. Fungal flora associated with Ips typographus: Frequency, virulence, and ability to stimulate the host defence reaction in relation to insect population levels. Can. J. For. Res. 2005, 35, 365-373. [CrossRef]

53. Viiri, H. Fungal associates of the spruce bark beetle Ips typographus L. (Col. scolytidae) in relation to different trapping methods. J. Appl. Entomol. 1997, 121, 529-533. [CrossRef]

54. Kotýnková-Sychrová, E. Mykoflóra chodeb kůrovců v Československu [The mycoflora of bark beetle galleries in Czechoslovakia.]. Česká Mykol. 1966, 20, 45-53.

55. Barbet-Massin, M.; Jiguet, F.; Albert, C.H.; Thuiller, W. Selecting pseudo-absences for species distribution models: How, where and how many? Methods Ecol. Evol. 2012, 3, 327-338. [CrossRef]

56. Doležal, P.; Sehnal, F. Effects of photoperiod and temperature on the development and diapause of the bark beetle Ips typographus. J. Appl. Entomol. 2007, 131, 165-173. [CrossRef]

57. Wermelinger, B.; Seifert, M. Analysis of the temperature dependant development of the spruce bark beetle Ips typographus (L.) (Col., Scolytidae). J. Appl. Entomol. 1998, 122, 185-191. [CrossRef]

58. Wermelinger, B. Ecology and management of the spruce bark beetle Ips typographus_a review of recent research. For. Ecol. Manag. 2004, 202, 67-82. [CrossRef]

59. Jönsson, A.M.; Harding, S.; Bärring, L.; Ravn, H.P. Impact of climate change on the population dynamics of Ips typographus in southern Sweden. Agric. For. Meteorol. 2007, 146, 70-81. [CrossRef]

60. Faccoli, M. Effect of weather on Ips typographus (Coleoptera Curculionidae) phenology, voltinism, and associated spruce mortality in the Southeastern Alps. Environ. Entomol. 2009, 38, 307-316. [CrossRef]

61. Netherer, S.; Panassiti, B.; Pennerstorfer, J.; Matthews, B. Acute drought is an important driver of bark beetle infestation in Austrian Norway spruce stands. Front. For. Glob. Chang. 2019, 2, 39. [CrossRef]

62. Christiansen, E.; Bakke, A. Does drought really enhance lps typographus epidemics? A scandinavian perspective. In Proceedings of the Integrating Cultural Tactics into the Management of Bark Beetle and Reforestation Pests, Vallombrosa, Italy, 1-3 September 1996; Grégoire, J.C., Liebhold, A.M., Stephen, F.M., Day, K.R., Salom, S.M., Eds.; USDA Forest Service General Technical Report NE-236. United States Department of Agriculture, Forest Service, Northeastern Forest Experiment Station: Radnor, PA, USA, 1997; pp. 163-171.

63. Swart, N.C.; Cole, J.N.; Kharin, V.V.; Lazare, M.; Scinocca, J.F.; Gillett, N.P.; Anstey, J.; Arora, V.; Christian, J.R.; Hanna, S. The Canadian earth system model version 5 (CanESM5. 0.3). Geosci. Model Dev. 2019, 12, 4823-4873. [CrossRef]

64. Séférian, R.; Nabat, P.; Michou, M.; Saint-Martin, D.; Voldoire, A.; Colin, J.; Decharme, B.; Delire, C.; Berthet, S.; Chevallier, M.; et al. Evaluation of CNRM earth system model, CNRM-ESM2-1: Role of earth system processes in present-day and future climate. J. Adv. Model. Earth Syst. 2019, 11, 4182-4227. [CrossRef]

65. Hajima, T.; Watanabe, M.; Yamamoto, A.; Tatebe, H.; Noguchi, M.A.; Abe, M.; Ohgaito, R.; Ito, A.; Yamazaki, D.; Okajima, H.; et al. Development of the MIROC-ES2L earth system model and the evaluation of biogeochemical processes and feedbacks. Geosci. Model Dev. 2020, 13, 2197-2244. [CrossRef] 
66. Meinshausen, M.; Nicholls, Z.R.J.; Lewis, J.; Gidden, M.J.; Vogel, E.; Freund, M.; Beyerle, U.; Gessner, C.; Nauels, A.; Bauer, N.; et al. The shared socio-economic pathway (SSP) greenhouse gas concentrations and their extensions to 2500. Geosci. Model Dev. 2020, 13, 3571-3605. [CrossRef]

67. O'Donnell, M.S.; Ignizio, D.A. Bioclimatic Predictors for Supporting Ecological Applications in the Conterminous United States; U.S. Geological Survey Data Series 691; U.S. Geological Survey: Reston, VA, USA, 2012; p. 10.

68. Marin, M.; Preisig, O.; Wingfield, B.D.; Kirisits, T.; Yamaoka, Y.; Wingfield, M.J. Phenotypic and DNA sequence data comparisons reveal three discrete species in the Ceratocystis polonica species complex. Mycol. Res. 2005, 109, 1137-1148. [CrossRef]

69. Ojeda Alayon, D.I.; Tsui, C.K.; Feau, N.; Capron, A.; Dhillon, B.; Zhang, Y.; Massoumi Alamouti, S.; Boone, C.K.; Carroll, A.L.; Cooke, J.E. Genetic and genomic evidence of niche partitioning and adaptive radiation in mountain pine beetle fungal symbionts. Mol. Ecol. 2017, 26, 2077-2091. [CrossRef]

70. Rice, A.V.; Thormann, M.N.; Langor, D.W. Mountain pine beetle-associated blue-stain fungi are differentially adapted to boreal temperatures. For. Pathol. 2008, 38, 113-123. [CrossRef]

71. Lieutier, F.; Yart, A.; Ye, H.; Sauvard, D.; Gallois, V. Variations in growth and virulence of Leptographium wingfieldii Morelet, a fungus associated with the bark beetle Tomicus piniperda L. Ann. For. Sci. 2004, 61, 45-53. [CrossRef]

72. R Core Team. R: A Language and Environment for Statistical Computing; R Foundation for Statistical Computing: Vienna, Austria, 2021; Available online: https:/ / www.R-project.org/ (accessed on 2 December 2021).

73. Thuiller, W.; Georges, D.; Engler, R.; Breiner, F. Biomod2: Ensemble Platform for Species Distribution Modeling. R Package Version 3.4.6. Available online: https:/ / cran.r-project.org/web/packages/biomod2/biomod2.pdf (accessed on 24 November 2021).

74. Muscarella, R.; Galante, P.J.; Soley-Guardia, M.; Boria, R.A.; Kass, J.M.; Uriarte, M.; Anderson, R.P. ENM eval: An R package for conducting spatially independent evaluations and estimating optimal model complexity for Maxent ecological niche models. Methods Ecol. Evol. 2014, 5, 1198-1205. [CrossRef]

75. Hothorn, T.; Bretz, F.; Westfall, P.; Heiberger, R.M.; Schuetzenmeister, A.; Scheibe, S. Package 'Multcomp'. Simultaneous Inference in General Parametric Models. Project for Statistical Computing, Vienna, Austria. Available online: https://cran.r-project.org/ web / packages/multcomp/multcomp.pdf (accessed on 24 November 2021).

76. Lenth, R.V.; Buerkner, P.; Herve, M.; Love, J.; Riebl, H.; Singmann, H. Package ‘Emmeans'. Available online: https:/ /cran.rproject.org/web/packages/emmeans/emmeans.pdf (accessed on 24 November 2021).

77. Araújo, M.B.; New, M. Ensemble forecasting of species distributions. Trends Ecol. Evol. 2007, 22, 42-47. [CrossRef]

78. U.S. Geological Survey. Digital representation of "Atlas of United States Trees" by Elbert L. Little, Jr. 1999. Available online: http:/ / esp.cr.usgs.gov/data/atlas/little/ (accessed on 24 November 2021).

79. Brockerhoff, E.G.; Liebhold, A.M. Ecology of forest insect invasions. Biol. Invasions 2017, 19, 3141-3159. [CrossRef]

80. Marini, L.; Haack, R.A.; Rabaglia, R.J.; Toffolo, E.P.; Battisti, A.; Faccoli, M. Exploring associations between international trade and environmental factors with establishment patterns of exotic Scolytinae. Biol. Invasions 2011, 13, 2275-2288. [CrossRef]

81. Lockwood, J.L.; Cassey, P.; Blackburn, T. The role of propagule pressure in explaining species invasions. Trends Ecol. Evol. 2005, 20, 223-228. [CrossRef]

82. Gauthier, S.; Bernier, P.; Kuuluvainen, T.; Shvidenko, A.Z.; Schepaschenko, D.G. Boreal forest health and global change. Science 2015, 349, 819-822. [CrossRef] [PubMed]

83. Millar, C.I.; Stephenson, N.L. Temperate forest health in an era of emerging megadisturbance. Science 2015, 349, 823-826. [CrossRef]

84. Chen, I.C.; Hill, J.K.; Ohlemuller, R.; Roy, D.B.; Thomas, C.D. Rapid range shifts of species associated with high levels of climate warming. Science 2011, 333, 1024-1026. [CrossRef]

85. Parmesan, C.; Yohe, G. A globally coherent fingerprint of climate change impacts across natural systems. Nature 2003, 421, 37-42. [CrossRef]

86. Weed, A.S.; Ayres, M.P.; Hicke, J.A. Consequences of climate change for biotic disturbances in North American forests. Ecol. Monogr. 2013, 83, 441-470. [CrossRef]

87. Ayres, M.P.; Lombardero, M.J. Assessing the consequences of global change for forest disturbance from herbivores and pathogens. Sci. Total Environ. 2000, 262, 263-286. [CrossRef]

88. Dukes, J.S.; Pontius, J.; Orwig, D.; Garnas, J.R.; Rodgers, V.L.; Brazee, N.; Cooke, B.; Theoharides, K.A.; Stange, E.E.; Harrington, R.; et al. Responses of insect pests, pathogens, and invasive plant species to climate change in the forests of northeastern North America: What can we predict? Can. J. For. Res. 2009, 39, 231-248. [CrossRef]

89. Sambaraju, K.; Goodsman, D. Mountain pine beetle: An example of a climate-driven eruptive insect impacting conifer forest ecosystems. CAB Rev. 2021, 16, 1-18. [CrossRef]

90. Sturrock, R.; Frankel, S.; Brown, A.; Hennon, P.; Kliejunas, J.; Lewis, K.; Worrall, J.; Woods, A. Climate change and forest diseases. Plant Pathol. 2011, 60, 133-149. [CrossRef]

91. Marini, L.; Ayres, M.P.; Battisti, A.; Faccoli, M. Climate affects severity and altitudinal distribution of outbreaks in an eruptive bark beetle. Clim. Chang. 2012, 115, 327-341. [CrossRef]

92. Linnakoski, R.; Mahilainen, S.; Harrington, A.; Vanhanen, H.; Eriksson, M.; Mehtätalo, L.; Pappinen, A.; Wingfield, M.J. Seasonal succession of fungi associated with Ips typographus beetles and their phoretic mites in an outbreak region of Finland. PLoS ONE 2016, 11, e0155622. [CrossRef] 